\title{
SOCIAL CONSCIOUSNESS IN THREE SHORT STORIES WRITTEN BY LEO TOLSTOY
}

\author{
Faiha Fakhari Mousa Alkayed \\ University of Tabuk - University College at Tayma. \\ (Email: faihaalkayed@yahoo.com)
}

Received date: 05-11-2019

Revised date: 14-11-2019

Accepted date: $28-12-2019$

Published date: 28-12-2019

To cite this document: Alkayed, F. F. M. (2019). Social Consciousness in Three Short Stories Written by Leo Tolstoy. International Journal of Humanities, Philosophy and Language, 2(8), 241-248.

DOI: $10.35631 / \mathrm{ijhpl} .280018$

Abstract: The paper presents a discussion of three selected short stories written by Leo Tolstoy namely: "God Sees the Truth but Wait, Three Questions, and What Men Live By". Thus, the aim of this paper is to reveal the social consciousness as appeared in such literary kind because awareness plays an important role in people's lives and all our lives are built on the awareness of things. However, it has been noticed that this work of Leo Tolstoy mirrors awareness of traditional and modern values and have thematic varieties, deep insight into human realities and characters. The stories of Leo Tolstoy represent an authentic and real picture of human life which considered being a convincing story.

Key Words: Consciousness, Tolstoy, Authentic, Short Story

\section{Introduction}

The consciousness in literature is a method of narration that describes happenings in the flow of thoughts in the characters minds. The term of consciousness initially written by psychologist William James in his researches. He writes (1983, p77) "it is nothing joined; it flows. A 'river' or a 'stream' is the metaphors by which it is most naturally described. In talking of it hereafter, let's call it the stream of thought, consciousness, or subjective life."

According to Allen (1981), a short story is a piece of prose fiction, normally upto10, 000 words that can be read in one sitting. Theoretically, it is a tool through which impressions, principles, values, and symbols are developed from the writer's perspective. Therefore, the author's personality, workplace and way of life are part of the short story (Green, 2004, p.311-327).In an attempt to describe their nature, Singer (2000, p.38-40) noted that 
sometimes short stories focus on a specific time, mystery or sensitive issue, but they always define consequences and results in order to developed the awareness of the reader.

Leo Tolstoy (1828-1910) was born in the south of Moscow to a well-known family of Old Russian nobility, considered one of the world's greatest novelists, Leo Nikolaevich Tolstoy is famous especially for the 19th-century classics. Although he was born into nobility, Leo Tolstoy spent much of his life as a champion of Russia's peasant class, notably in the field of education. He began his literary career in the 1850s, publishing a trilogy about his own life: Childhood, Boyhood, and Youth (Gale, 2016).

Tolstoy served in the Russian army during the Crimean War, and his book Sevastopol Sketches which contain a lot of stories was well-received in literary circles and praised for its realistic depiction of war (Tolstoj, 2013). After traveling throughout Europe, Leo Tolstoy returned to the family estate and devoted himself to raising a family and writing his great psychological novels and stories such as War and Peace, Anna Karenina, God Sees the Truth but Wait, Three Questions, and What Men Live By. From the 1880s until his death, he devoted himself to more spiritual and philosophical matters, writing several essays on ethics and morals and coming to terms with his Christian conversion described in 1879's Confessions (Anargyros, 2002). Tolstoy has his elitist views on awareness, He wrote: "Everyone thinks of changing the world, but no one thinks of changing himself which make our path narrow and perilous owing to the low of awareness".

\section{Literature Review}

Ashima Gayon (2016) conducted a study entitled "reflection of social consciousness in the short story of Akhon Nodir Mritut" written by Mahim Bora. This study describes that writing is a reflection of society. It mirrors the genuine picture and echoes the genuine feeling and sentiments it contains. Since society is never static, it changes with the change of time and different types of writing attempt to keep the pace of the fluctuated changes in society. We discover particular qualities of authors of every time i.e. the duty, liabilities, and mindfulness towards the general public which reflects in their works. In short stories, change can be seen in the author's social duty and eagerness to change the general public. These excellent manifestations have constantly made a colossal impact on the minds of the readers. One turns out to be clear about Mahim Bora's dynamic standpoints towards the general public and the ability to rise among the general population through his innovative fascinating works. Through his compositions, he passes on the message to the masses of each age that we discovered in the archives of history. Along these lines, it is exceptionally evident that interminable endeavors are to be made with genuineness and assurance to grab away our rights. In the flood of life, we should always remember our particular self or claim. At exactly that point, we can have the capacity to gain our ground and also the progress of our general public.

Yirsaw (2016) conducted a study entitled "Narrative mode: A comparative study on selected short stories of Leo Tolstoy and Edgar Allan Poe". The study refers to the method of narration to provide a short story and focuses on the style of narration and narratives. The study shows that the narrator has experience in reading literary work and concentrates on its technical structure like some scholars such as Roland Barth. The study suggests that narrative 
should be taken as a central point of inquiry for narrative strategies such as sound, angle, time, and narration. It discusses the narratives within the framework of its most important aspects and methods. The study also discussed the narrative situation in the literary texts through story and presentation, the direct and indirect mode of narration method.

Another study entitled "Social consciousness in the short stories of Rabindranath and Premchand: A comparative study" conducted by Bhattacharjee (2004) compared between Hindi and Bengali short stories. The study discussed the relationship between literature and society by analyzing the social, political, economic and religious background, focusing on political consciousness in the short stories. The study specifically discovered the nature of contemporary social issues. The diverse ways of the arrangements of social issues of Rabindranath and Premchand are due to the difference in their viewpoint. This difference was due to the contrast between the informed and dynamic culture of Bengali and the immature society of the Hindi. In any case, despite this fundamental difference in the state of mind, the literary style of the two scholars, the basic bond that brings them close to each other and the target of their works which makes one reciprocal of the other is that, the two extraordinary authors similarly stressed over the social issues of their time and sought to discover an arrangement in their stories.

Moreover, the arrangement of the social issues was their awesome obligation as authors. As they uncovered the social issues existing in the focal point of their stories, so they broke them down in their stories. In this way, we may say that despite a few contrasts all over, both Rabindranath and Premchand composed their stories for the general population. Thus, Rabindranath in Bengali writing and Premchand in Hindi, the two biggest scholars, have procured deathless acclaim and transcendence, not confined by time and space. From my point of view, the study is a leap on the external economic, political and religious aspects without entering into the subject matter, which is social awareness.

\section{Theoretical Framework}

The paper will explain the content, structure, and functions of the messages contained in selected stories written by Leo Tolstoy. Textual analysis will be used in this paper. McKee (2003, p.4) defines a text as "something that we make meaning from" such as books, magazines, newspapers, TV programs, historical documents, articles, and interviews. Barthes (1975, p.237-272) stated that "the theory of text can coincide only with practice of writing". Mostly textual analysis relies on a judgment of similarity between significant units. This method is a categorization procedure for perceiving, differentiating and understanding these units. Categorization depends on similarity and distinctiveness (Tversky, 1977, p.327-352).

There are many literary schools of thought, each with its own approach for the analysis of texts. Meaning and connotation that the text seeks to communicate to the readers vary depending on the type of literary work. Structural analysis focuses on signs and indicators that appear in the text (Morris \& Hirst, 1991, p.21-48). It looks beyond the border of the text, seeking to analyze the signs and determine their significance and understand their meanings explicitly in the surface structure (Bressler, 2007). Researchers use textual analysis as a technique to translate the attributes of a written or verbal message. The rationale behind literary analysis is to describe the content, structure and functions messages contained in 
writing (Frey, 1999). Therefore, the first step is to provide a summary of the selected text, so that the reader will become familiar with the text and know the incidents of stories. The researcher will also have a better understanding and a clear picture of the stories. The second step in this study will consist of textual analysis to explore the deep meaning in the selected stories written by Edgar Allan Poe and Leo Tolstoy. The researcher need to understand the text and read it more than once to understand the relationship between the elements and purpose of writing the story, and relate the text to surrounding environment. The third steps will consist of identifying the ideas and the subject and indicating the interconnection between the sub-ideas and the general ideas. Then the direction of the images portrayed in the stories will be analyzed. Finally, the researcher will determine the type of purpose, depth, internal structure, external structure.

\section{Discussion}

Leo Tolstoy was a Russian writer who primarily wrote novels and short stories. Later in life, he also wrote plays and essays. His two most famous stories "What Men Live By" and "Three Questions" are acknowledged as two of the greatest stories of all time and a pinnacle of realist fiction (Gustafson, 2014). The following story "The Three Questions" for Tolstoy tells the tale of a king who strives to find answers to what he considers lives most important, yet hardest to answer, questions: He had it proclaimed throughout his kingdom that he would give a great Reward to anyone who would teach him what was the right time for every action, and who were the most necessary People and how he might know what was the most important thing to do, some critics describe this story, it has a large idea of awareness to the reader.

To answer these questions the king chooses the wise hermit which showed his foresightedness and intelligence "When the King approached, the hermit was digging the ground in front of his hut" (p.2). It was clear from the action of the hermit that he was in no mood to accept the king's disguised appearance provides enough evidence to understand the answer to his three questions. So he took a tough test of the king to let the king practically experience the purpose of God's creation and accept the truth that only when you do good you serve God and fulfill His purpose and find perfect success, peace, and happiness. It was the inherent nature of the king to do well and be good. And this is what gained the strength and pleasure of the story to help the reader to complete his reading and understand the story to take more advantage for it and take more awareness from this story. In other words, we can describe the awareness that the author wants to convey to the reader by asking questions and searching for answers. The answer to these questions is as follows: The right time for any job is the current time we live, and the most necessary people in life are the people who are around you, the thing a person must do is help people, "Send his own physician to attend him and promised to restore his property" (p.3).

The second story which I have chosen, "God Sees the Truth But Waits" In this short story, Tolstoy instigates many questions in readers, mind about truth, injustice and fate as he resides his readers between both spiritual and materialistic worlds throughout the course of the story. In spite of the fact that this story is a realistic fiction, it attracted our attention due to the allegory it implies and the significance of the values it reveals. Above all, it could happen physically (Forgeard, 2008). 
The title of the story holds an implied allegorical meaning according to the plot. Having a first look to the title "God sees the Truth, but waits" arouses the question why God waits as long as He sees the truth? And leaves the reader restless as it gives the sense of suspense to discover the notion behind it. The events of the story one by one feed the reader's sense of suspense with contentment as well as astonishment.

The story has an obvious relationship with the author Leo Tolstoy; it was first published in 1872, the period that Tolstoy was experiencing his journey looking for a meaning to the life then finally found the religion as the most proper to get over the burdens of anxieties he suffered from. The story is a clear reflection of Tolstoy's religious concepts which he carried in that period and latter on (jahn, 1975). In addition, the story is centered about forgiveness justice and injustice and give the reader more consciousness in alive.

Tolstoy indirectly leads the readers to infer the true value of faith and forgiveness and the importance of their outcomes by deducing that through Ivan's character. The fact which Tolstoy wants to teach the readers is that God is the only one who knows the complete truth about everything, including our realities. But He sometimes may lead us to discover our realities through some slight or even harsh trials. In the case of Ivan, at the beginning he is described to be full of fun and a heavy drinker also indirectly to be unaware of his reality.

But after being convicted and suspected even by the closest person to him, his wife, he returns to God as he says, "It seems that only God can know the truth, it is to Him alone we must appeal, and from Him alone expect mercy". (p.4) Thus, Tolstoy shows the readers the significance of the faith in our life, as in the story, the Ivan character believes that only God is capable of showing the truth. Yet, Ivan is exposed to face another trial to prove his real charity, when he encounters his enemy the Makar character, the readers may expect a destructive reaction from him towards Makar, but just the opposite happens, and Ivan tells Makar "God will forgive you. Maybe I am a hundred times worse than you". (p.3) the two characters both come to the understanding that God's forgiveness and mercy towards humans are incomprehensible. Therefore, here, readers realize that outcomes of faith are crucial to the life as it makes the whole person to change towards the best and to develop both spiritually and morally.

In this discussion, it is been attempted to analyze all the literary important characteristics of the short story of God Sees the Truth, but Waits by the famous Russian novelist, Tolstoy's aim in this story is to bring up reader's attention to realize the importance of faith and its significance in the process of moralizing the members of the society and to build up a correct notion about a materialistic aspect of their life. This story encourages the reader to trust in God more. Although Ivan is suffering being far away from his family and still waiting for the truth after a very long year, God gave him what he was asking. And God will still give justice. Hadiati asserted this (2011), in her study about "A MORPHOLOGICAL ANALYSIS OF ENGLISH COMPOUND WORDS IN TOLSTOY".

Regarding the third story "What Men Live By" The logic in Tolstoy's beloved and inspirational story seems a bit convoluted at times but gets sorted out if the subtle shades of 
meaning are attended to. The three truths that the displaced angel learns answer the questions: What dwells in man, what is not given to man, and what men live by. The answers were revealed through daily living experiences in the shoemaker's cottage. One meaning of "significance" is the belief, Allah with you and takes care for everything this is the consciousness in this story.

Where the ideas that the writer wants to deliver to the reader at the beginning of this story and at the end of these sites of the story of Leo Tolstoy embodied two types of awareness are: helping others and faith in God. The story begins with a very poor shoemaker visiting some of his customers who owe him money, with the hope of receiving payment and thereby buying sheepskins for a coat. He and his wife, who remain unnamed in the first section, only have one old coat between them. But the customers don't pay up. The shoemaker complaints of one who has far more than his family does a house, cattle, and wheat to make their own flour, yet the customer held back his wages.

At the shrine, Michael was starving, freezing, and in much pain. When Simon had first walked near and then right on by Michael, he was concerned with himself and his family only, and Michael felt horror. But, "Suddenly I heard the man coming back. I looked and could not recognize the man I had seen before. Then there had been death in his face, but now he had suddenly become a living soul, and in his face, I recognized God" (p.5).

From last select, Michael glowed because he was an angel, and he had been a man up until then due to God's discipline. He had smiled at (only) three different times during his time on earth because, each time, he had learned one of the things God said he needed to understand. What were those things that he needed to know before God's punishment was over? Simon wanted to know and learn too. But before Michael told Simon and his wife the divine lessons, he started at the beginning, explaining how he saw Simon's spirit before he took him home.

The reader draws his information through the sequence of events and access to what can be understood from this story to benefit from it as follows: What is given to men? When Matrena character had softened up after her initial anger and gave Michael food, Michael saw God in her. Then he understood what is given to men: love and it dwells in their hearts.

What is not given to men? Michael learned what was not given to men when he saw the wealthy man who had ordered the boots, and the angel of death near him. The wealthy man didn't realize that when he ordered boots to last a year, he would be dead that day and not need them. What is not given to men is the knowledge of what they need.

The Michael character learned also about what men live by through the outcome of the twin girls, that they had been taken in, cared for, and dearly loved by a stranger. Michael had been the angel ordered to take the soul of the girls' mother to God, but after the mother's pleadings Michael disobeyed God and didn't take her soul. He did go and talk with God about it, and God's response was to send Michael back to take the mother's soul and then make him human until he learned three things about man (the items in this list). The first two things relate to the last. Men have love, but men don't really know what they need, so "all men live, 
not by reason of any care they have for themselves, but by the love for them that is in other people" (p.4).

In any time, may people see God in us as we think of them more than ourselves, and as we give out of compassion rather than hold back out of rash judgment. Lord, may you be in us and your glory be seen by all.

Leo Tolstoy embodies the image of the hero in this story in the form of an angel, which gave this story a religious character and was rich in pestle and guidance. Tolstoy was an eclectic on world religions, Basically, he was a religious naturalist. Despite being the world's most famous writer at his death, Tolstoy died with a dysfunctional family and a set of disciples who couldn't agree enough to form a cohesive unit. the awareness of this story appears in the last section when the angel understand what happened with him, for this reason, we can say now the stories of Leo Tolstoy have a large awareness to make the societies more progressive than the past time, Gustafson asserted this idea in him research about "Leo Tolstoy: Resident and Stranger" (2014).

\section{Conclusion}

The purpose of this paper was to discover the consciousness in the short stories of Leo Tolstoy and to find awareness in it. A discussion of Leo's stories Each time Tolstoy stands up for an ideal, or acts to improve the lot of things, or strikes out against injustice, he sends forth a tiny ripple of hope and crossing each other from a million different centers of energy and daring, those ripples build a current that can sweep the walls of readers and society.

Leo Tolstoy best articulated the concept of social consciousness in some quote stories. Nelson Mandela asserted that, the idea that every human being has the opportunity to effect change in the world through positive social action is exciting and empowering (Nelson, 2006). However, one must first be aware of injustice and develop a social consciousness before one can take action.

Where Leo Tolstoy focuses on all his stories on the hero and makes him the main engine of the story and make changes and the delivery of ideas and information to the reader in some of his stories the hero is poor and what is rich and other and all indicate the reality of the writer and many of the experiences that passed in his life and all reflected in his stories.

In attempting to demonstrate the social consciousness in the short stories of Tolstoy, we have examined some of his stories from two viewpoints - the characteristics of social consciousness, and the picture of hero how coming in these stories. Regarding the writings of Leo Tolstoy many people looking that they are written with the pen of a poet. The critics preferred to stay away from his stories because in their opinion, they were realistic, romantic creations, products of his imagination.

\section{References}

Anargyros-Klinger, A. (2002). The thread of depression throughout the life and works of Leo 
Ashima Gayon. (2016). Article Title Reflection of Social Consciousness in The Short Story.

Title Dimorian Review E-Journal. Retrieved from

http://www.dimorianreview.com/2016/07/reflection-of- socialconsciousness-in.html.

Allen, W. E. (1981). The short story in English. Oxford University Press, USA.

Barthes, Roland and Lionel Duisit. (1975). "An Introduction to the Structural Analysis of

Bhattacharjee, M. (2004). Social consciousness in the short stories of Rabindranath and Premchand a comparative study.

Bressler, C. E. (2007). Literary criticism. An Introduction to theory and practice. Franco, Z; Blau, K.; Zimbardo, P. (2011). "Heroism: A conceptual analysis and differentiation between heroic action and altruism". Review of General Psychology. 5 (2): 99113.doi:10.1037/a0022672.

Brooker, P., Selden, R., \& Widdowson, P. (2017). A reader's guide to contemporary literary.

Forgeard, M. (2008). Linguistic styles of eminent writers suffering from unipolar and bipolar.

Frey, L., Botan, C., \& Kreps, G. (1999). Investigating communication: An introduction to research methods. (2nd ed.) Boston: Allyn\& Bacon.

Gustafson, R. F. (2014). Leo Tolstoy: Resident and Stranger (Vol. 998). Princeton University Press.

Green, M. C., Brock, T. C., \& Kaufman, G. F. (2004). Understanding media enjoyment: The role of transportation into narrative worlds. Communication Theory, 14(4), 311-327.

Gale, C. L. (2016). A Study Guide for Leo Tolstoy's" Death of Ivan Ilych". Gale, Cengage

Gustafson, R. F. (2014). Leo Tolstoy: Resident and Stranger. Princeton University Press.

Hadiati, C. (2011). A MORPHOLOGICAL ANALYSIS OF ENGLISH COMPOUND WORDS http://www.anc.org.za/ancdocs/ speeches/nobelnrm.html > $\quad \begin{array}{lll}9 & \text { IN }\end{array}$ TOLSTOYâ€TM S GOD SEES THE TRUTH BUT WAITS. Lensa: Kajian

Jahn, G. R. (1975). A Structural Analysis of Leo Tolstoy's" God Sees the Truth, But July 2006). Kebahasaan, Kesusastraan, dan Budaya, 1(2).

James, W., \& Burkhardt, F. H. (1983). The Principles of Psychology, the Works of William James.

Laird, A. (Ed.). (2006). Ancient literary criticism. Oxford University Press on Demand. Learning.

McKee, A. (2003). Textual analysis: A beginner's guide. London, Thousand Oaks and New Delhi: Sage Publications (p. 4). mood disorder. Creativity Research Journal, 20(1), 8192.

Morris, J., \&Hirst, G. (1991). Lexical cohesion computed by thesaural relations as an indicator of the structure of text. Computational linguistics, 17(1), 21-48.

Narrative. "New Literary History. Vol. 6, Issue 2. pp. 237-272.

Nelson Mandela, "Nelson Mandela's Nobel Peace Prize Address," theory. Taylor \& Francis. Tolstoy. The International Journal of Psychoanalysis, 83(2), 407-418.

Singer, Marilyn. (2000) "What is a Short Story?" The ALAN Review, Volume 28, Number 1, p.38-40.

Tversky, A (1977). Features of 'similarity', Psychological Review, 84(4): 327-352. Waits". Studies in Short Fiction, 12(3), 261.

Tolstoj, L. N. (2013). Sevastopol'skie rasskazy. Tbilisi State University.

Yirsaw, L. (2016). Narrative Mode: A comparative Study on Selected Short Stories of Leo Tolstoy and Edgar Allan Poe. World Journal of English Language, 6(3), p24. 